\title{
OCCUPATIONAL RISK ASSESSMENT OF OXIDATIVE STRESS AND GENOTOXICITY IN WORKERS EXPOSED TO PAINTS DURING A WORKING WEEK
}

\section{CARINA CASSINI ${ }^{1}$, CAROLINE CALLONI ${ }^{1}$, GIOVANA BORTOLINI ${ }^{1}$, SOLANGE CRISTINA GARCIA ${ }^{2}$, MARCO AURÉLIO DORNELLES ${ }^{3}$, JOÃO ANTÔNIO PÊGAS HENRIQUES ${ }^{1}$, BERNARDO ERDTMANN ${ }^{1}$, and MIRIAN SALVADOR ${ }^{1,3}$}

${ }^{1}$ Universidade de Caxias do Sul, Rio Grande do Sul, Brazil

Laboratório de Estresse Oxidativo e Antioxidantes, Centro de Ciências Agrárias e Biológicas, Instituto de Biotecnologia

${ }^{2}$ Universidade Federal do Rio Grande do Sul, Rio Grande do Sul, Brazil

Faculdade de Farmácia

${ }^{3}$ Universidade de Caxias do Sul, Rio Grande do Sul, Brazil

Centro de Ciências da Saúde

\begin{abstract}
Objectives: Paints are complex mixtures of solvents and metals that can induce health damages in workers exposed to them. The aim of the present work was to evaluate possible oxidative and genotoxic effects in workers exposed to paints. Material and Methods: Peripheral blood and buccal cell samples were collected from 33 workers exposed to paints and 29 non-exposed workers (controls) during an ordinary working week (Monday morning and Friday evening). Oxidative markers were assessed using thiobarbituric acid assay, carbonylated proteins, superoxide dismutase and catalase activities. Hippuric acid and delta-aminolevulinic acid were determined as biomarkers of toluene and lead exposure, respectively. Genotoxicity was measured through comet assay and micronucleus (MN) frequencies. Results: The exposed group showed higher hippuric acid and delta-aminolevulinic acid levels (Friday samples) and lower superoxide dismutase activity (Monday samples) in relation to control group. DNA damage index (comet assay) was higher in the exposed group, both in Monday and Friday samples, compared to the control group. No differences were observed in frequency of micronuclei (MN) between the groups, either in lymphocytes or buccal cells. However, the exposed group presented an increase (Monday samples) in nuclear buds frequency in lymphocytes - a marker of gene amplification as well as an increase in condensed chromatin in the buccal cells (Monday and Friday samples), suggesting induction of apoptosis. Furthermore, a decrease in the nuclear division index (Friday samples) was observed in the exposed group, indicating that paint exposure induces cytostatic effects in lymphocytes. Conclusion: The results suggest that individuals exposed to paints have increased levels of DNA damage.
\end{abstract}

Key words:

Paint exposure, Oxidative stress, Genotoxicity

Received: 26 Jan 2011. Accepted: 27 May 2011.

Address reprint request to C. Cassini, Universidade de Caxias do Sul, Laboratório de Estresse Oxidativo e Antioxidantes, 1130, Rua Francisco Getúlio Vargas, Caxias do Sul, Rio Grande do Sul, Brasil, ZIP code 95070-560 (e-mail: msalvado@ucs.br). 


\section{INTRODUCTION}

Paint workers are occupationally exposed to a variety of organic solvents, including aromatic hydrocarbons (mainly toluene), aliphatic hydrocarbons, ketone, alcohols and esters, and metals such as aluminum, titanium, cobalt, chromium and lead [1-3]. Despite the fact that some of these compounds are not considered carcinogenic by the International Agency for Research on Cancer (IARC), a mixture of them or some individual metals can contribute to increase the risk of cancer [4,5], neurological issues [6], hearing loss [7], and hepatic [8] and respiratory [9] diseases. The exact mechanism of such damages is not fully understood, but it is known that occupational exposure to organic solvents [3,10-12] and some metals [13-15] can induce oxidative stress and DNA damages. Nonetheless, the occupational exposure to paints is poorly studied. There are some reports about DNA damage induction by paint exposure [16-19], however, it was also demonstrated that paint/organic solvents exposure was not able to induce mutagenic effects in paint workers [3,20].

A wide range of methods is currently being used for detecting early biological effects of DNA-damaging agents in occupational settings. The single cell gel electrophoresis or comet assay has been proven to be a sensitive method for investigating DNA damage in human biomonitoring. The comet assay detects strand breaks, alkali-labile sites, DNA crosslinking, and incomplete excision repair [21]. These damages could, or could not be repaired [3]. Another wellestablished cytogenetic technique to assess DNA damage in occupational exposure is the micronucleus (MN) test [22]. This cytogenetic mutational test detects historical accumulation of mutagenic events and does not require metaphasic cells. It is a valuable tool for studying the most important occupational and environmental hazard to public health [3]. A previous work from our group showed that even using protective personal equipment (PPEs), workers handling anti-tumoral drugs presented genotoxic damages, which varied along the working week [23]. Therefore, the aim of the present work was to evaluate oxidative stress markers and potential genotoxic effects in workers occupationally exposed to paints, before the working week (Monday morning) and after the weekly exposure (Friday evening). Plasma oxidative damages to lipids and proteins were analyzed using thiobarbituric acid reactive substances (TBARS) and carbonylated proteins (CP) assays, respectively, and through the activity of the antioxidant enzymes: superoxide dismutase (SOD) and catalase (CAT). Genotoxicity was evaluated in peripheral blood (comet assay) and in lymphocytes and exfoliated buccal cells (MN assay). Hippuric acid (HA), the main metabolite resulting from toluene exposure [3], and urine delta-aminolevulinic acid (ALA), a marker for lead exposure [24], were also assayed.

\section{MATERIAL AND METHODS}

\section{Ethical issues}

The study was approved by the Ethical Committee of Universidade de Caxias do Sul. In accordance with the Declaration of Helsinki, all subjects were advised about the procedure and signed the informed consent prior to participation in this study.

\section{Subjects}

The exposed group consisted of 33 men occupationally exposed to paints - for at least 6 months - from metal-mechanic industries of Caxias do Sul, RS, Brazil. Twenty-nine males, non-exposed and matched by age to the exposed group, were chosen for the control group. All of them were healthy, non-smokers and were not under any medication. A personal questionnaire about work and lifestyle was answered by all individuals.

\section{Collection of biological material}

Blood samples were obtained by venipuncture, using vacutainers with heparin as anticoagulant. Buccal cells were collected with small-headed toothbrushes by rotating 
them 20 times in a circular motion, starting from a central spot and gradually increasing in circumference to produce an outward spiral effect. Both cheeks were sampled. Urine samples were collected into a plastic container without preservatives. Blood and oral cells were taken on Monday in the early morning and on Friday evening. Urine samples were collected on Friday evening. The samples were refrigerated and immediately transported to the laboratory.

\section{Biochemical analysis}

Oxidative lipid damages were measured spectrophotometrically by the concentration of the TBARS [25]. Results were expressed as nmol/mL. The oxidative damage to proteins was assessed by determining carbonyl groups based on the reaction with 2,4-dinitrophenylhydrazine (DNPH) (E. Merck), as previously described [26]. Results were expressed as nmol/mg of protein. SOD activity was determined by measuring the inhibition of the rate of auto-catalytic adrenochrome formation at $480 \mathrm{~nm}$, in a reaction medium containing $1 \mathrm{mM}$ adrenaline $(\mathrm{pH}=2.0)$ and $50 \mathrm{mM}$ glycine ( $\mathrm{pH}=10.2$ ) (both from E. Merck), as described by Bannister and Calabrese [27]. The reaction was conducted at $30^{\circ} \mathrm{C}$ for $3 \mathrm{~min}$. Results were expressed as units/g of protein. One unit was defined as the amount of enzyme that results in 50\% inhibition of the rate of adrenochrome formation. CAT activity was measured according to the method described by Aebi [28]. The assay principle is based on determining the rate of hydrogen peroxide $\left(\mathrm{H}_{2} \mathrm{O}_{2}\right.$, E. Merck) decomposition at $240 \mathrm{~nm}$. The reaction was conducted at $30^{\circ} \mathrm{C}$ for $1 \mathrm{~min}$. Results were expressed as units/g of protein. One unit is defined as the amount of enzyme that decomposes $1 \mu \mathrm{mol} \mathrm{H}_{2} \mathrm{O}_{2}$ per minute at $\mathrm{pH}=7.4$ and $30^{\circ} \mathrm{C}$. Total protein levels were measured by the Biuret method (Bioclin, K 031, Brazil) for spectrophotometric determination at $545 \mathrm{~nm}$. Results were expressed as $\mathrm{mg} / \mathrm{dl}$ of plasma. All of these oxidative stress markers were analyzed in plasma samples. HA quantification was performed in urine by high performance liquid chromatography (HPLC) with a K 2501 UV/VIS detector operated by Eurochrom 2000 software (Knauer, Berlin, Germany). The $225 \mathrm{~nm}$ wavelength was chosen according to Laffon et al [29]. The chromatographic separation was achieved using a reversed-phase column Eurospher-100 $150 \times 4 \mathrm{~mm}$ with $5-\mu \mathrm{m}$ particle size. The mobile phase consisted of a mixture of $\mathrm{KH}_{2} \mathrm{PO}_{4} 25 \mathrm{mM}$ in acetic acid $1 \%$ - acetonitrile $(90: 10, \mathrm{v} / \mathrm{v})$ with $\mathrm{pH}=3.5$. The flow rate was $0.8 \mathrm{ml} / \mathrm{min}$, and the analyses were performed under ambient temperature. Total run time was $30 \mathrm{~min}$. Results were expressed as $\mathrm{g} / \mathrm{g}$ of creatinine. Analysis of urinary ALA was carried out spectrophotometrically through Ehrlich's reagent [24]. Results were expressed as $\mathrm{mg} / \mathrm{g}$ of creatinine. Creatinine concentration was measured by spectrophotometry, using a routine laboratory kit (Doles Reagentes, Goiânia, GO, Brazil).

\section{Gentoxicity assays}

Single cell gel electrophoresis or comet assay was performed to assess potential genotoxic effects in the exposed group. Blood samples were transported to the laboratory under refrigeration $\left(10\right.$ to $\left.20^{\circ} \mathrm{C}\right)$ and processed immediately. A standard protocol was adopted for comet assay preparation and analysis [30]. Slides were prepared by mixing $5 \mu \mathrm{l}$ whole blood and $95 \mu \mathrm{l}$ low melting point agarose $(0.75 \%)$ (Pronadisa). The mixture was poured onto a frosted microscope slide coated with normal melting point agarose (1.5\%) (Agargen). After solidification, the coverslip was removed and the slides were placed in lysis solution [2.5 M NaCl, $100 \mathrm{mM}$ ethylenediaminetetraacetic acid (EDTA) and $10 \mathrm{mM}$ Tris, $\mathrm{pH}=10.0-10.5$, with freshly added $1 \mathrm{ml}$ Triton X-100 and $10 \%$ dimethyl sulfoxide, all from E. Merck] for a minimum period of $1 \mathrm{~h}$ and a maximum of 5 days. Subsequently, the slides were incubated in freshly made alkaline buffer $(300 \mathrm{mM} \mathrm{NaOH}$ and $1 \mathrm{mM}$ EDTA, $\mathrm{pH}=12.6$, both from E. Merck) for $10 \mathrm{~min}$. The DNA was electrophoresed for $20 \mathrm{~min}$ at $25 \mathrm{~V}(0.9 \mathrm{~V} / \mathrm{cm})$ 
and $300 \mathrm{~mA}$, and the buffer was neutralized with $0.4 \mathrm{M}$ Tris $(\mathrm{pH}=7.5)$. Finally, DNA was stained with silver nitrate, and the slides were coded for blind analysis. The electrophoresis procedures and the efficiency for each electrophoresis run were checked using negative and positive internal controls consisting of whole human blood collected in the laboratory: the negative internal control being whole blood and the positive internal control whole blood mixed with methyl methanesulfonate (M4016/Sigma, St. Louis, MO) to $8 \times 10^{-5} \mathrm{M}$ final concentration. This mixture was incubated at $37^{\circ} \mathrm{C}$ for $2 \mathrm{~h}$. Images of 100 randomly selected cells (50 cells from each of two replicated slides) were analyzed from each sample. Each electrophoresis run was considered valid only if the negative and positive controls yielded the expected results. The damages were visually scored according to tail size into five classes, from no tail (0) to maximal (4) long tail, resulting in a single DNA damage score for each subject and, consequently, for each study group. Therefore, a group damage index (DI) could range from 0 (all cells with no tail, 100 cells $\times 0$ ) to 400 (all cells with maximally long tails, 100 cells $\times 4$ ).

To assess possible mutagenic effects, MN assay was performed in binucleated lymphocytes and buccal cells. Lymphocyte cultures were set up by adding $0.3 \mathrm{ml}$ blood to $5 \mathrm{ml}$ standard culture RPMI 1640 medium (Nutricell, Campinas, SP, Brazil) containing 20\% fetal calf serum and $1 \%$ (v/v) phytohemaglutinin. Two cultures per subject were established. The flasks were cultured at $37^{\circ} \mathrm{C}$ for $44 \mathrm{~h}$ before adding $5 \mu \mathrm{g} / \mathrm{ml}$ of cytochalasin B (Sigma), and incubation was continued until reaching total time of $72 \mathrm{~h}$. After incubation, lymphocytes were harvested by centrifugation at $800 \mathrm{rpm}$ for $5 \mathrm{~min}$ and fixed in methanol:acetic acid (3:1), without hypotonic treatment, and dropped onto clean slides. Staining was performed with Giemsa 5\% $(\mathrm{pH}=6.7)$. One thousand binucleated lymphocytes per sampling were scored for the presence of MN, nucleoplasmic bridges (NPBs) and nuclear buds (NBUDs) with microscopy at a magnification of 200-1000x, according to Fenech [22]. Calculation of the nuclear division index (NDI) was made according to Fenech [22], following the formula:

$$
\mathrm{NDI}=(\mathrm{M} 1+2 \mathrm{M} 2+3 \mathrm{M} 3+4 \mathrm{M} 4) / 500
$$

where M1-M4 represents the number of cells with 1-4 nuclei and $\mathrm{N}$ is the total number of viable cells scored.

For the MN assay in buccal cells, the heads of the brushes used to collect the samples were individually placed into separate tubes containing $20 \mathrm{ml}$ of buccal cell buffer (BC, $0.01 \mathrm{M}$ Tris-HCl, 0.1 M EDTA tetra sodium salt, $0.02 \mathrm{M}$ sodium chloride, all from E. Merck) at $\mathrm{pH}=$ 7.0. Cells of both right and left cheeks were mixed and centrifuged for $10 \mathrm{~min}$ at $1500 \mathrm{rpm}$. The supernatant was removed and replaced by $10 \mathrm{ml}$ of fresh BC buffer. Cells were spun and washed other three times. One sample was applied to clean microscope slides and fixed with methanol absolute. The slices were stained with Giemsa 5\%. The criterion of scoring cells with $\mathrm{MN}$ and other anomalies was the same as described by Thomas et al. [31]. We scored one thousand cells for each sampling. Results were expressed as the frequency of abnormal cells per 1000 cells.

\section{Statistical analysis}

The results were presented as mean plus standard error. Comparisons between groups were performed using ANOVA and Tukey's post-hoc test. Relation between variables was assessed with Pearson's correlation coefficient. SPSS version 12.0 (SPSS, Chicago, IL) was used in all statistical analyses.

\section{RESULTS}

\section{Characteristics of the study population}

The main characteristics of the exposed group are shown in Table 1. No difference between the age of the exposed (36.94 \pm 11.69 years) and the control group (39.14 \pm 7.53 
years) was observed. The exposed group had been working with painting for 0.5 to 26 years with a daily paint exposure of 1 to $12 \mathrm{~h}$. None of the workers reported the wearing of complete personal protective equipment - PPE (mask, gloves, protective clothes and glasses), 39.4\% of the workers reported having worn three PPEs (mask, gloves and protective clothes) and $60.6 \%$ of them reported wearing of only one or two of the PPEs mentioned. No differences were observed in relation to drinking and eating habits between the exposed and non-exposed groups (data not shown).

\section{Biochemical assays}

The exposed group did not show any significant increase in TBARS levels in relation to the control group (Table 2 and Figure 1). However, in the exposed group, lipid damages were higher in Friday samples than in Monday samples $(p=0.027)$. In addition, it was observed that workers
Table 1. Characterization of the exposed group $(\mathrm{N}=33)$

\begin{tabular}{lc}
\hline \multicolumn{1}{c}{ Characteristic } & Value \\
\hline Age (years) & \\
mean \pm SE & $36.94 \pm 2.03$ \\
range & $18-61$ \\
Average working time (years) & \\
$\quad$ mean \pm SE & $9.10 \pm 1.35$ \\
range & $0.50-26.00$ \\
Daily paint exposure time (hours) & \\
$\quad$ mean \pm SE & $5.60 \pm 0.54$ \\
range & $1-12$ \\
Use of individual protection equipment (PPE) $(\%)$ & \\
$\quad$ use of mask, gloves and protective clothes & 39.40 \\
use of one or two of the PPE mentioned above & 60.60 \\
\hline SE - standard error. &
\end{tabular}

exposed to paints had lower SOD $(\mathrm{p}=0.003)$ in Monday samples (Table 2).

Table 2. Oxidative stress markers in Monday and Friday samples from the control $(\mathrm{N}=29)$ and exposed $(\mathrm{N}=33)$ groups

\begin{tabular}{clcccc}
\hline Group & \multicolumn{1}{c}{ Day } & TBARS $(\mathrm{nmol} / \mathrm{ml})$ & $\begin{array}{c}\text { Carbonylated } \\
\text { proteins } \\
\text { (nmol DNPH/ } \\
\text { mg proteins) }\end{array}$ & $\begin{array}{c}\text { Superoxide dismutase } \\
\text { (U SOD/g proteins) }\end{array}$ & $\begin{array}{c}\text { Catalase } \\
\text { (U CAT/mg proteins) }\end{array}$ \\
\hline Control group & Monday samples & & & \\
& mean \pm SE & $5.46 \pm 0.18$ & $11.12 \pm 0.91$ & $3.56 \pm 0.49$ & $2.41 \pm 0.36$ \\
& min-max & $3.43-7.09$ & $2.95-19.50$ & $0.29-10.21$ & $0.57-4.85$ \\
& Friday samples & & & & \\
& mean \pm SE & $5.76 \pm 0.13$ & $7.71 \pm 0.68^{*}$ & $3.22 \pm 0.43$ & $1.63 \pm 0.19$ \\
& min-max & $3.73-6.91$ & $3.18-13.64$ & $0.72-8.81$ & $0.00-3.27$ \\
& Monday samples & & & & \\
& mean \pm SE & $5.22 \pm 0.33$ & $9.39 \pm 0.88$ & $1.71 \pm 0.25^{* *}$ & $2.60 \pm 0.59$ \\
& min-max & $1.55-10.24$ & $2.05-23.41$ & $0.08-6.75$ & $0.00-6.08$ \\
& Friday samples & & & & $2.54 \pm 0.38$ \\
& mean \pm SE & $6.20 \pm 0.27^{*}$ & $8.88 \pm 0.39$ & $2.23 \pm 0.33$ & $0.29-5.84$ \\
\hline
\end{tabular}

SE - standard error.

* Values significantly different from Monday samples in the same group by ANOVA, Tukey's post-hoc test; $\mathrm{p} \leq 0.05$.

** Values significantly different from control group by ANOVA, Tukey's post-hoc test; $\mathrm{p} \leq 0.05$. 

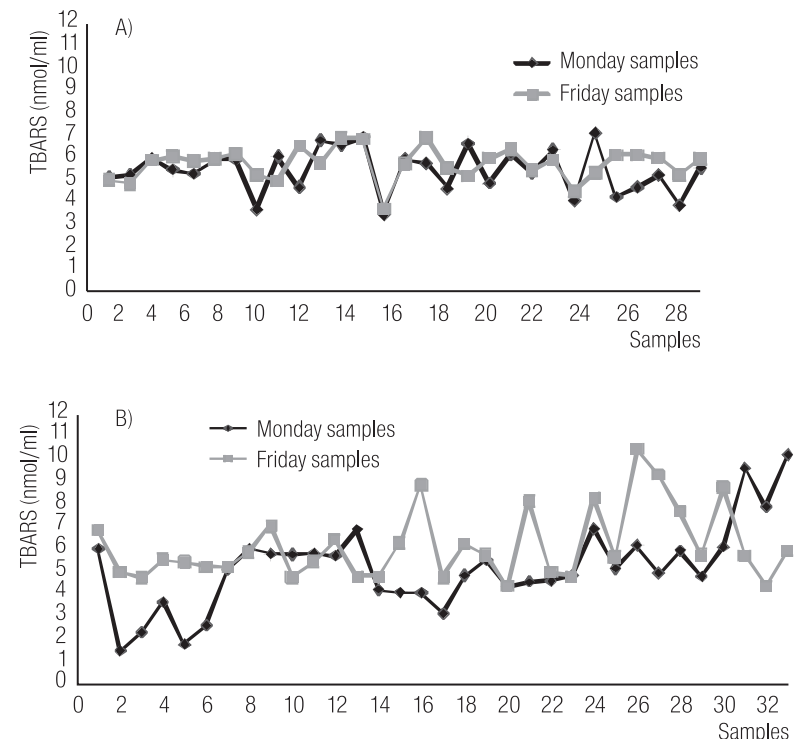

Fig. 1. Individual TBARS values in control (A) and exposed (B) groups.

According to Brazilian regulation [32], HA and ALA levels in the exposed group were within normal values (HA up to $1.5 \mathrm{~g} / \mathrm{g}$ creatinine; ALA up to $4.5 \mathrm{mg} / \mathrm{g}$ creatinine). However, it is important to mention that both HA and ALA were higher in the exposed group $($ HA: $p=0.025$; ALA: $p=0.000)($ Table 3$)$. A positive correlation was observed between HA concentration and time of daily paint exposure $(r=0.420 ; p=0.015)$.

\section{Genotoxicity assays}

A genotoxic effect (comet assay) was found in the exposed group both in Monday and Friday samples in relation to the control group (Monday samples, $p=0.000$; Friday samples, $p=0.000)$. In the exposed group, the DNA damage index in Friday samples was higher than in Monday samples $(p=0.033)$ (Table 4). DNA damage classes one (Monday samples, $p=0.000$; Friday samples, $p=0.000$ ) and two (Monday samples, $p=0.000$; Friday samples, $p=0.000$ ) in the exposed group were higher than those observed in the control group, which showed a higher frequency of undamaged DNA (Table 4). None of the workers who
Table 3. Hippuric acid and delta-aminolevulinic acid in control group $(\mathrm{N}=29)$ and exposed group $(\mathrm{N}=33)$ in Friday samples

\begin{tabular}{ccc}
\hline Group & $\begin{array}{c}\text { Hippuric acid } \\
\text { (g/g creatinine })\end{array}$ & $\begin{array}{c}\text { Delta-aminolevulinic } \\
\text { acid } \\
(\mathrm{mg} / \mathrm{g} \text { creatinine })\end{array}$ \\
\hline Control group & & \\
mean \pm SE & $0.25 \pm 0.03$ & $0.76 \pm 0.07$ \\
min-max & $0.01-0.69$ & $0.40-2.47$ \\
Exposed group & & \\
mean \pm SE & $0.52 \pm 0.08$ & $1.63 \pm 0.14$ \\
min-max & $0.20-1.58$ & $0.11-2.84$ \\
\hline
\end{tabular}

$\mathrm{SE}$ - standard error.

* Values significantly different from control group by ANOVA, Tukey's post-hoc test; $\mathrm{p} \leq 0.05$.

wore three PPEs (mask, gloves and protective clothes) presented DNA damage class four in the comet assay (data not shown). Positive correlation between DNA damage index and age (Friday samples, $\mathrm{r}=0.371$; $p=0.034)$ was observed.

No statistical difference was detected in lymphocyte (Table 5) and buccal cell (Table 6) MN frequency between the exposed and control groups. However, an increase in NBUD (Monday samples, $p=0.024$ ) and a decrease in NDI (Friday samples, $p=0.000$ ) were observed in binucleated lymphocytes of the exposed group (Table 5). Buccal cells of the exposed group showed higher condensed chromatin cells frequency both in Monday and Friday samples (Monday samples, $p=0.000$; Friday samples, $p=0.000)$ (Table 6). Although no increase in $\mathrm{MN}$ frequency was observed, a positive correlation between MN frequency in lymphocytes and daily exposure time was found (Monday samples, $r=0.433 ; p=0.024)$. Furthermore, the daily exposure time was positively correlated to NBUD frequency $(r=0.420 ; p=0.029)$. Positive correlations between NBUD and NPB (Monday samples, $r=0.640$, $\mathrm{p}=0.000)$ were also observed. 
Table 4. DNA damage index (comet assay) and frequency (\%) of the different classes of DNA damage in Monday and Friday samples from the control $(\mathrm{N}=29)$ and exposed $(\mathrm{N}=33)$ groups

\begin{tabular}{|c|c|c|c|c|c|c|c|}
\hline \multirow{2}{*}{ Group } & \multirow{2}{*}{ Day } & \multirow{2}{*}{$\begin{array}{c}\text { DNA damage } \\
\text { index (comet assay) } \\
\text { (Arbitrary units) }\end{array}$} & \multirow{2}{*}{$\begin{array}{l}\text { Undamaged } \\
\text { cells }\end{array}$} & \multicolumn{4}{|c|}{ Damage class } \\
\hline & & & & one & two & three & four \\
\hline \multirow{6}{*}{$\begin{array}{l}\text { Control } \\
\text { group }\end{array}$} & \multicolumn{7}{|c|}{ Monday samples } \\
\hline & mean $\pm \mathrm{SE}$ & $34.04 \pm 2.29$ & $66.03 \pm 2.18$ & $33.79 \pm 2.16$ & $0.17 \pm 0.14$ & $0.00 \pm 0.00$ & $0.00 \pm 0.00$ \\
\hline & $\min -\max$ & $14.00-62.00$ & $39.00-86.00$ & $14.00-60.00$ & $0.00-4.00$ & $0.00-0.00$ & $0.00-0.00$ \\
\hline & \multicolumn{7}{|c|}{ Friday samples } \\
\hline & mean $\pm S E$ & $30.11 \pm 2.08$ & $68.69 \pm 2.58$ & $31.38 \pm 2.61$ & $0.31 \pm 0.12$ & $0.00 \pm 0.00$ & $0.00 \pm 0.00$ \\
\hline & $\min -\max$ & $9.00-15.00$ & $22.00-91.00$ & $9.00-78.00$ & $0.00-3.00$ & $0.00-0.00$ & $0.00-0.00$ \\
\hline \multirow{6}{*}{$\begin{array}{l}\text { Exposed } \\
\text { group }\end{array}$} & \multicolumn{7}{|c|}{ Monday samples } \\
\hline & mean $\pm \mathrm{SE}$ & $61.48 \pm 3.09$ & $43.30 \pm 2.34^{* *}$ & $51.33 \pm 2.03^{* *}$ & $4.15 \pm 0.69^{* *}$ & $0.45 \pm 0.28$ & $0.12 \pm 0.12$ \\
\hline & $\min -\max$ & $24.00-112.00$ & $23.00-76.00$ & $24.00-74.00$ & $0.00-17.00$ & $0.00-8.00$ & $0.00-4.00$ \\
\hline & \multicolumn{7}{|c|}{ Friday samples } \\
\hline & mean $\pm \mathrm{SE}$ & $71.42 \pm 2.77^{*(* *)}$ & $35.76 \pm 1.93^{*(* *)}$ & $57.79 \pm 1.75^{* *}$ & $5.70 \pm 0.71 * *$ & $0.73 \pm 0.36$ & $0.03 \pm 0.03$ \\
\hline & $\min -\max$ & $38.00-118.00$ & $15.00-63.00$ & $36.00-81.00$ & $0.00-15.00$ & $0.00-9.00$ & $0.00-1.00$ \\
\hline
\end{tabular}

$\mathrm{SE}$ - standard error.

* Values significantly different from Monday samples in the same group by ANOVA, Tukey's post-hoc test; $p \leq 0.05$.

** Values significantly different from control group by ANOVA, Tukey's post-hoc test; $\mathrm{p} \leq 0.05$.

The cells were assessed visually and received scores from 0 (undamaged) to 4 (maximally damaged), according to the size and shape of the tail [3].

Table 5. Frequencies of micronuclei, nuclear buds and nucleoplasmic bridges, and nuclear division index in lymphocytes in Monday and Friday samples from the control $(\mathrm{N}=29)$ and exposed $(\mathrm{N}=27)$ groups

\begin{tabular}{|c|c|c|c|c|c|}
\hline Group & Day & $\begin{array}{l}\text { Micronuclei / } 1000 \\
\text { binucleated cells }\end{array}$ & $\begin{array}{c}\text { Nuclear buds / } 1000 \\
\text { binucleated cells }\end{array}$ & $\begin{array}{c}\text { Nucleoplasmic } \\
\text { bridges / } 1000 \\
\text { binucleated cells }\end{array}$ & $\begin{array}{l}\text { Nuclear division } \\
\text { index }{ }^{* * *}\end{array}$ \\
\hline \multirow[t]{6}{*}{ Control group } & Monday samples & & & & \\
\hline & mean $\pm \mathrm{SE}$ & $2.55 \pm 0.17$ & $1.76 \pm 0.19$ & $1.28 \pm 0.20$ & $1.23 \pm 0.01$ \\
\hline & $\min -\max$ & $1.00-4.00$ & $0.00-4.00$ & $0.00-4.00$ & $1.10-1.40$ \\
\hline & Friday samples & & & & \\
\hline & mean $\pm \mathrm{SE}$ & $2.93 \pm 0.26$ & $2.93 \pm 0.31$ & $1.28 \pm 0.16$ & $1.92 \pm 0.06^{*}$ \\
\hline & $\min -\max$ & $0.00-6.00$ & $0.00-6.00$ & $0.00-3.00$ & $1.10-2.37$ \\
\hline \multirow[t]{6}{*}{ Exposed group } & Monday samples & & & & \\
\hline & mean $\pm \mathrm{SE}$ & $2.93 \pm 0.24$ & $2.93 \pm 0.31^{* *}$ & $1.93 \pm 0.35$ & $1.42 \pm 0.07$ \\
\hline & $\min -\max$ & $1.00-5.00$ & $0.00-7.00$ & $0.00-7.00$ & $1.10-2.19$ \\
\hline & Friday samples & & & & \\
\hline & mean $\pm \mathrm{SE}$ & $2.89 \pm 0.25$ & $3.19 \pm 0.35$ & $1.70 \pm 0.35$ & $1.41 \pm 0.07 * *$ \\
\hline & $\min -\max$ & $1.00-5.00$ & $0.00-6.00$ & $0.00-5.00$ & $1.09-2.15$ \\
\hline
\end{tabular}

SE - standard error.

* Values significantly different from Monday samples in the same group by ANOVA, Tukey's post-hoc test; $\mathrm{p} \leq 0.05$.

** Values significantly different from control group by ANOVA, Tukey's post-hoc test; $\mathrm{p} \leq 0.05$.

*** The nuclear division index (NDI) was calculated following the formula: NDI $=(\mathrm{M} 1+2 \mathrm{M} 2+3 \mathrm{M} 3+4 \mathrm{M} 4) / 500$, where M1-M4 represent the number of cells with 1-4 nuclei and $\mathrm{N}$ is the total number of viable cells scored. 
Table 6. Frequency of micronuclei, nuclear buds, binucleated, pyknotic, karyolitic, karyorrhetic and condensed chromatin cells in buccal cells in Monday and Friday samples from the control $(\mathrm{N}=29)$ and exposed $(\mathrm{N}=27)$ groups

\begin{tabular}{|c|c|c|c|c|c|c|c|c|}
\hline Group & Day & $\begin{array}{l}\text { Micronuclei } \\
\text { / } 1000 \text { cells }\end{array}$ & $\begin{array}{l}\text { Nuclear buds } \\
\text { / } 1000 \text { cells }\end{array}$ & $\begin{array}{c}\text { Binucleated } \\
\text { cells / } 1000 \\
\text { cells }\end{array}$ & $\begin{array}{l}\text { Pyknotic cells } \\
\text { / } 1000 \text { cells }\end{array}$ & $\begin{array}{c}\text { Karyolytic } \\
\text { cells / } 1000 \\
\text { cells }\end{array}$ & $\begin{array}{c}\text { Karyorrhetic } \\
\text { cells / } 1000 \\
\text { cells }\end{array}$ & $\begin{array}{l}\text { Condensed } \\
\text { chromatin } \\
\text { cells / } 1000 \\
\text { cells }\end{array}$ \\
\hline \multirow{6}{*}{$\begin{array}{r}\text { Control } \\
\text { group }\end{array}$} & \multicolumn{8}{|c|}{ Monday samples } \\
\hline & mean $\pm \mathrm{SE}$ & $1.52 \pm 0.23$ & $0.28 \pm 0.11$ & $10.52 \pm 1.41$ & $0.79 \pm 0.25$ & $26.93 \pm 3.02$ & $12.79 \pm 1.98$ & $6.41 \pm 0.82$ \\
\hline & $\min -\max$ & $0.00-4.00$ & $0.00-2.00$ & $3.00-31.00$ & $0.00-6.00$ & $5.00-62.00$ & $0.00-54.00$ & $0.00-18.00$ \\
\hline & \multicolumn{8}{|c|}{ Friday samples } \\
\hline & mean $\pm \mathrm{SE}$ & $1.97 \pm 0.26$ & $0.38 \pm 0.16$ & $6.45 \pm 4.92^{*}$ & $1.86 \pm 0.52$ & $40.66 \pm 3.87^{*}$ & $12.10 \pm 1.99$ & $3.83 \pm 1.18$ \\
\hline & $\min -\max$ & $0.00-5.00$ & $0.00-4.00$ & $1.00-21.00$ & $0.00-12.00$ & $11.00-96.00$ & $1.00-47.00$ & $0.00-31.00$ \\
\hline \multirow{6}{*}{$\begin{array}{c}\text { Exposed } \\
\text { group }\end{array}$} & \multicolumn{8}{|c|}{ Monday samples } \\
\hline & mean $\pm \mathrm{SE}$ & $1.96 \pm 0.25$ & $0.41 \pm 0.57$ & $9.30 \pm 5.53$ & $1.04 \pm 0.26$ & $26.07 \pm 3.54$ & $10.44 \pm 1.78$ & $18.74 \pm 2.35^{* *}$ \\
\hline & $\min -\max$ & $0.00-4.00$ & $0.00-2.00$ & $0.00-22.00$ & $0.00-5.00$ & $10.00-79.00$ & $0.00-31.00$ & $1.00-47.00$ \\
\hline & \multicolumn{8}{|c|}{ Friday samples } \\
\hline & mean $\pm S E$ & $1.44 \pm 0.21$ & $0.22 \pm 0.08$ & $7.41 \pm 4.41$ & $0.56 \pm 0.20$ & $36.30 \pm 3.39$ & $8.22 \pm 1.13$ & $18.63 \pm 2.38^{* *}$ \\
\hline & $\min -\max$ & $0.00-4.00$ & $0.00-1.00$ & $0.00-17.00$ & $0.00-5.00$ & $14.00-83.00$ & $0.00-22.00$ & $1.00-46.00$ \\
\hline
\end{tabular}

SE - standard error.

* Values significantly different from Monday samples in the same group by ANOVA, Tukey's post-hoc test; $\mathrm{p} \leq 0.05$.

**Values significantly different from control group by ANOVA, Tukey's post-hoc test; $p \leq 0.05$.

\section{DISCUSSION}

Biological monitoring of exposure to deleterious chemicals is important in the evaluation of risks to human health and it is considered a strategy to improve conditions of occupational safety. In this sense, the present work evaluated possible toxic effects in individuals occupationally exposed to paints. Paints contain a heterogeneous group of chemicals that are difficult to classify because manufactures often fail to disclose the complete composition of their products. However, according to the labels, the studied workers were exposed to toluene, xylene, ethylbenzene, butyl and ethyl acetate, acetone, methyl isobutyl ketone, titanium, aluminum, lead, cobalt, and chromium. It is already known that these compounds can induce DNA damages [15,33-35] and an increase in oxidative stress levels $[13,15,36,37]$. However, the effects induced by the mixture of them are still controversial.

Increase in TBARS levels in the exposed group in relation to the control group was not observed. However, Friday samples from the exposed group presented higher levels of TBARS than those observed in Monday samples, showing an increase in oxidative lipid damages during the week (Table 2) probably due to the exposure to paints.

Antioxidant enzymes are important to counteract the damages induced by oxidative stress. The first line of enzymatic defence includes the action of SOD and CAT. SOD catalyzes the superoxide anion dismutation to $\mathrm{H}_{2} \mathrm{O}_{2}$ and CAT catalyzes the decomposition of $\mathrm{H}_{2} \mathrm{O}_{2}$ to water [38]. In our work, we observed a decrease in SOD activity in the exposed group in relation to the control group in Monday 
samples (Table 2). It is known that both solvents and metals can generate oxidative stress [39-42], which could be partially reduced by these enzymes. The decrease in SOD activity observed in this work suggests the formation of superoxide radical by paints, which possibly depleted the enzyme.

Organic solvents [3,12,42], metals [13-15] and paints $[2,16,17]$ can also induce DNA damages. In fact, in the present work, an increase in DNA damages (comet assay) was observed in workers exposed to paints in both Monday and Friday samples. In the exposed group, these damages were higher in Friday samples than in Monday samples (Table 4). It is reasonable to suggest that the weekend is important to reduce, at least in part, the damages induced by paints.

On the other hand, no increase was observed in micronuclei levels in the exposed group (Table 5), showing that the DNA damages detected through comet assay were being repaired. Although many works have shown an increase in micronuclei frequency in painters [17-19] another work [20] has already reported no differences in this cytogenetic parameter in workers exposed to paints, which agrees with our results. Furthermore, a study on human lymphocytes showed that some solvents found in paints (toluene, benzene and acetone) were unable to induce formation of micronuclei [43].

Positive results in the comet assay do not always correspond to positive results in the MN tests, especially when the exposure to genotoxic agents is small. The comet assay usually detects more damages than the MN test [44]. While MN assay detects injuries that survive for at least one mitotic cycle, comet assay identifies reparable injuries or alkali-labile sites [3]. Consequently, it is important to use both tests to get more reliable results [17].

Besides the detection of $\mathrm{MN}$, this technique also allows the checking of other endpoints of genotoxin-exposed populations, such as NBUDs, NPBs and NDI. NBUDs are a biomarker of gene amplification, NPBs provide a measure of chromosome rearrangement, and the NDI index is a biomarker of the proliferative status of the viable cell fraction [22]. An increase in NBUD frequency was observed in binucleated lymphocytes of the exposed group in Monday samples compared to Monday samples of the control group (Table 5), suggesting chromosomal damage and/or a DNA instability status in this group [22]. Shimizu et al. [45] showed that the amplified DNA of mammalian cells was selectively localized to specific sites at the periphery of the nucleus and eliminated via nuclear budding. However, the duration of the nuclear budding process remain unknown. The positive correlation between NBUD frequencies and daily exposure time (Friday samples; $r=0.420 ; p=0.029$ ) suggests that this abnormality could be induced by the exposure to the complex mixture of compounds present in paints. In fact, an increase in NBUD frequency in workers exposed to polycyclic aromatic hydrocarbons has already been reported [11]. A decrease in NDI in Friday samples was also found in the exposed workers (Table 5), suggesting a possible cytostatic effect induced by paints and/or a delay in the cellular division process in order to better repair their DNA damages [46]. This is the first work to explore this kind of nuclear abnormalities in painters, and the biological meaning of these findings should be better evaluated.

Among the different analytical procedures available, the biomonitoring assays using exfoliated cells from the buccal mucosa has shown its utility for the evaluation of genotoxic damage [47]. It has been already suggested [48] that to study DNA damages due to occupational exposure to toxic agents, it seems necessary to use both lymphocytes and buccal exfoliated cells. Besides, evaluation of MN, exfoliated cells of mucosa also provides evidence of other nuclear abnormalities, such as NBUDs (small nuclei linked to the nucleus by a narrow or wide stalk of nucleoplasmic material), binucleated cells (presence of two nuclei within a cell), pyknotic cells (small shrunken nucleus with a high-density material), karyolytic cells (nuclear 
dissolution), karyorrhetic cells (nuclear fragmentation), and condensed chromatin cells (speckled or striated nucleus) [49]. Binucleus formation is considered as an indicator of cytotoxicity, pyknotic cells are linked to cell death, karyorrhexis and karyolysis are considered as indicators of later apoptosis, while condensed chromatin is considered as an indicator of early stages of apoptosis [30]. Although no increase in MN frequency was observed in the present work, the exposed group showed increased frequency of condensed chromatin in buccal cells in Monday and Friday samples compared to the control group (Table 6), suggesting the beginning of an apoptotic process [30], which could be related to reactive oxygen species generation and/or antioxidant depletion [38]. It has already been shown that some solvents, such as benzene, are able to increase condensed chromatin frequency in exfoliated cells from the oral mucosa [50]. The correlation found between the average working time and the index of DNA damage in Friday samples and between daily exposure to paints and MN and NBUDs shows that, despite the wearing of any PPE, workers presented DNA damages and these damages were probably related to paint exposure.

According to the Brazilian regulation [51], protective clothes, masks, gloves and glasses are PPEs that must be provided to the workers exposed to organic solvents. Although none of the workers in this study declared to wear complete PPEs, the ALA and HA levels matched the Brazilian rules. However, it should be noted that these workers presented DNA damage and nuclear abnormalities. This lack of appropriate use of PPEs together with a potential passive exposure could be associated, at least in part, to the molecular damages observed in this work. The data presented herein show that workers occupationally exposed to paints present DNA damages, as demonstrated through comet assay, as well as other abnormalities found in their DNA. The damages detected in the comet assay were repaired, since no alterations in $\mathrm{MN}$ levels were observed between both groups. However, the presence of DNA abnormalities should be better evaluated in order to establish their biological importance to the workers' health. Both comet and MN assays have shown to be very sensitive tests to measure DNA damages and could be used to improve the monitoring of paint workers.

\section{ACKNOWLEDGMENTS}

The authors thank all volunteers who participated in this study and the Corpo de Bombeiros of Caxias do Sul. The authors would also like to thank Dr. Ana Cristina Andreazza (University of British Columbia), Dr. Caroline Dani and MSc. Gustavo Scola (Universidade de Caxias do Sul) for their contributions. This work was supported by Coordenação de Aperfeiçoamento de Pessoal de Nível Superior (CAPES), Fundação de Amparo à Pesquisa do Rio Grande do Sul (FAPERGS) and Conselho Nacional de Desenvolvimento Científico e Tecnológico (CNPq).

\section{REFERENCES}

1. Pinto D, Ceballos JM, García G, Guzmán P, Del Razo LM, Vera $\mathrm{E}$, et al. Increased cytogenetic damage in outdoor painters. Mutat Res 2000;467:105-11.

2. Lee K-H, Ichiba M, Zhang J, Tomokuni K, Hong Y-C, Ha M, et al. Multiple biomarkers study in painters in a shipyard in Korea. Mutat Res 2003;540:89-98.

3. Heuser VD, Erdtmann B, Kvitko K, da Silva J. Evaluation of genetic damage in Brazilian footwear-workers: biomarkers of exposure, effect, and susceptibility. Toxicology 2007;232:235-47.

4. IARC. Inorganic and organic lead compounds. Monograph on the evaluation of the carcinogenic risk of chemicals to humans. IARC Press, Geneva, 2007.

5. Scélo G, Metayer C, Zhang L, Wiemels JL, Aldrich MC, Selvin S, et al. Household exposure to paint and petroleum solvents, chromosomal translocations, and the risk of childhood leukemia. Environ Health Perspec 2009;117:133-9.

6. Chen R, Dick F, Seaton A. Health effects of solvent exposure among dockyard painters: Mortality and neuropsychological symptoms. Occup Environ Med 1999;56:383-7. 
7. Rabinowitz PM, Galusha D, Slade MD, Dixon-Ernst C, O'Neill A, Fiellin M, et al. Organic solvent exposure and hearing loss in a cohort of aluminum workers. Occup Environ Med 2008;65:230-5.

8. Kaukiainen A, Vehmas T, Rantala K, Nurminen M, Martikainen R, Taskinen H. Results of common laboratory tests in solvent-exposed workers. Int Arch Occup Environ Health 2004;77:1432-46.

9. Park J, Lee CG, Ryu SY. Factors related to the prevalence of respiratory symptoms in workers in a petrochemical complex. J Occup Health 2006;48:216-22.

10. Bayil S, Cicek H, Cimenci IG, Hazar M. How volatile organic compounds affect free radical and antioxidant enzyme activity in textile workers. Arh Hig Rada Toksikol 2008;59:283-7.

11. Duan H, Leng S, Pan Z, Dai Y, Niu Y, Huang C, et al. Biomarkers measured by cytokinesis-block micronucleus cytome assay for evaluating genetic damages induced by polycyclic aromatic hydrocarbons. Mutat Res 2009;677:93-9.

12. Marczynski B, Pesch B, Wilhelm M, Rossbach B, Preuss R, Hahn J-U, et al. Occupational exposure to polycyclic aromatic hydrocarbons and DNA damage by industry: a nationwide study in Germany. Arch Toxicol 2009;83:947-57.

13. Mateuca R, Aka PV, De Boeck M, Hauspie R, KirschVolders M. Influence of hOGG1, XRCC1 and XRCC3 genotypes on biomarkers of genotoxicity in workers exposed to cobalt or hard metals dusts. Toxicol Lett 2005;156:277-88.

14. Mohammad IK, Mahdi AA, Raviraja A, Najmul I, Iqbal A, Thuppil V. Oxidative stress in painters exposed to low lead levels. Arh Hig Rada Toksikol 2008;59:161-9.

15. Liu HH, Lin MH, Liu PC, Chan CI, Chen HL. Health risk assessment by measuring plasma malondialdehyde (MDA), urinary 8-hydroxydeoxyguanosine (8-OH-dG) and DNA strand breakage following metal exposure in foundry workers. J Hazard Mater 2009;170:699-704.

16. Zhu CQ, Lam TH, Jiang CQ. Lymphocyte DNA damage in bus manufacturing workers. Mutat Res 2001;491:173-81.

17. Martino-Roth MG, Viégas J, Roth DM. Occupational genotoxicity risk evaluation through the comet assay and the micronucleus test. Genet Mol Res 2003;2:410-7.
18. Testa A, Festa F, Ranaldi R, Giachelia M, Tirindelli D, De Marco A et al. A multi-biomarker analysis of DNA damage in automobile painters. Environ Mol Mutagen 2005;46:182-8.

19. Aksoy H, Yilmaz S, Çelik M, Yüzbasioglu D, Ünal F. Genotoxicity study in lymphocytes of offset printing workers. J Appl Toxicol 2006;26:10-5.

20. Cárdenas-Bustamante O, Varona-Uribe M, Patiño-Florez RI, Groot-Restrepo H, Sicard-Suarez D, Tórrez-Carvajal MM, et al. Exposición a solventes orgánicos y efectos genotóxicos en trabajadores de fábricas de pinturas de Bogotá. Rev Salud Pública 2007;9:275-88.

21. Collins AR. The comet assay for DNA damage and repair: principles, applications, and limitations. Mol Biotechnol 2004;26:249-61.

22. Fenech M. Cytokinesis-block micronucleus cytome assay. Nat Protoc 2007;2:1084-104.

23. Rombaldi F, Cassini C, Salvador M, Saffi J, Erdtmann B. Occupational risk assessment of genotoxicity and oxidative stress in workers handling anti-neoplastic drugs during a working week. Mutagenesis 2009;24:1-6.

24. Tomokuni K, Ogata M. Simple method for determination of urinary d-aminolevulinic acid as an index of lead exposure. Clin Chem 1972;18:1531-6.

25. Wills ED. Mechanism of lipid peroxide formation in animal tissues. Biochem J 1966;99:667-76.

26. Levine RL, Garland D, Oliver CN, Amici A, Climent I, Lenz A-G, et al. Determination of carbonyl content in oxidatively modified proteins. Methods Enzymol 1990;186:464-78.

27. Bannister JV, Calabrese L. Assays for SOD. Methods Biochem Anal 1987;32:279-312.

28. Aebi H. Catalase in vitro. Methods Enzymol 1984;105:121-6. 29. Laffon B, Lema M, Méndez J. Simultaneous high-performance liquid chromatographic determination of urinary mandelic and phenylglyoxylic acids as indirect evaluation of styrene exposure. J Chromatogr B Biomed Sci Appl 2001;753:385-93.

30. Collins AR, Oscoz AA, Brunborg G, Gaivão I, Giovanneli L, Kruszewski M, et al. The comet assay: topic issues. Mutagenesis 2008; 23:143-51. 
31. Thomas P, Sarah H, Gruner T, Fenech M. The buccal cytome and micronucleus frequency is substantially altered in Down's syndrome and normal ageing compared to young healthy controls. Mutat Res 2008;638:37-47.

32. Ministério do Trabalho. Norma Regulamentadora NR 7 Programa de controle médico de saúde ocupacional. Portaria SSST ñ24, Brasília (DF); 1994.

33. Gurr JR, Wang AS, Chen CH, Jan KY. Ultrafine titanium dioxide particles in the absence of photoactivation can induce oxidative damage to human bronchial epithelial cells. Toxicology 2005;213:66-73.

34. Keegan GM, Learmonth ID, Case CP. A systematic comparison of the actual, potential, and theoretical health effects of cobalt and chromium exposures from industry and surgical implants. Crit Rev Toxicol 2008;38:645-74.

35. Bulat P, Potkonjak B, Dujic I. Lipid peroxidation and antioxidative enzyme activity in erythrocytes of workers occupationally exposed to aluminum. Arh Hig Rada Toksikol 2008;59:81-7.

36. Reeves JF, Davies SJ, Dodd NJ, Jha AN. Hydroxyl radicals $(\bullet \mathrm{OH})$ are associated with titanium dioxide $\left(\mathrm{TiO}_{2}\right)$ nanoparticle-induced cytotoxicity and oxidative DNA damage in fish cells. Mutat Res 2008;640:113-22.

37. Torres CH, Varona ME, Lancheros A, Patiño RI, Groot H. DNA damage assessment and biological monitoring of occupational exposure to organic solvents. Biomedica 2008;28:126-38.

38. Halliwell B, Gutteridge JMC. Free Radicals in Biology. 3rd ed. New York: Oxford University Press; 2007.

39. Costa C, De Pasquale R, Silvari V, Barbaro M, Catania S. In vitro evaluation of oxidative damage from organic solvent vapours on human skin. Toxicol In Vitro 2006;20:324-31.

40. Valko M, Morris H, Cronin MTD. Metals, toxicity and oxidative stress. Current Med Chem 2005;12:1161-208.

41. Revilla A, Pestana CR, Pardo-Andreu GL, Santos AC, Uyemura SA, Gonzales ME, et al. Potential toxicity of toluene and xylene evoked by mitochondrial uncoupling. Toxicol In Vitro 2007;21:782-8.
42. Roma-Torres J, Teixeira JP, Silva S, Laffon B, Cunha LM, Méndez J, et al. Evaluation of genotoxicity in a group of workers from a petroleum refinery aromatics plant. Mutat Res 2006;604:19-27.

43. Zarani F, Papazafiri P, Kappas A. Induction of micronuclei in human lymphocytes by organic solvents in vitro. J Environ Path Toxicol Oncol 1999;18:21-8.

44. Goethem FV. Comparative evaluation of the in vitro micronucleus test and the alkaline single cell gel electrophoresis assay or the detection of DNA damaging agents: Genotoxic effects of cobalt powder, tungsten carbide and cobalt-tungsten carbide. Mutat Res 1997;392:31-43.

45. Schimizu N, Shimuara T, Tanaka T. Selective elimination of acentric double minutes from cancer cells through the extrusion of micronuclei. Mutat Res 2000;448:81-90.

46. Kirsch-Volders M, Fenech M. Inclusion of micronuclei in non-divided mononuclear lymphocytes and necrosis/apoptosis may provide a more comprehensive cytokinesis block micronucleus assay for biomonitoring purposes. Mutagenesis 2001;16:51-8.

47. Pelclova D, Cerna M, Pastorkova A. Study of the genotoxicity of toluene. Arch Environ Health 2000;55:268-72.

48. Faust F, Kassie F, Knasmüller S, Kevekordes S, Mersch-Sundermann V. Use of primary blood cells for the assessment of exposure to occupational genotoxicants in human biomonitoring studies. Toxicology 2004;198:341-50.

49. Tolbert PE, Shy CM, Allen JW. Micronuclei and other nuclear abnormalities in buccal smears: methods and development. Mutat Res 1992;271:69-77.

50. Meireles JRC, Lopes MA, Alves NN, Cerqueira E de MM. Apoptosis in exfoliated cells from the oral mucosa of individuals occupationally exposed to mutagenic and carcinogenic agents. Rev Bras Cancerol 2006;52:337-43.

51. Ministério do Trabalho. Norma Regulamentadora NR 6 Equipamento de proteção individual. Portaria SIT no25, Brasília (DF); 2001.

This work is available in Open Access model and licensed under a Creative Commons Attribution-NonCommercial 3.0 Poland License - http://creativecommons.org/ licenses/by-nc/3.0/pl/deed.en. 